\title{
6.18 Артпроекти в системі дизайн-освіти
}

Через аналіз прототипів чи архетипів, з чого і розпочинається будь-який творчий процес у навчальних дисциплінах для спеціальності 022 «Дизайн», сучасник має можливість пізнати секрети і етапи формотворення, прийоми та засоби, особливості творчого підходу видатних майстрів минулого. Ознайомлення з українськими традиціями та досвідом, напрацьованим в процесі важкого творчого становлення особистості, дозволяє дизайнерові формуватись, вчить черпати та трансформувати ідеї для створення нових сучасних форм, $\mathrm{i}$ водночас бути ретранслятором і особливим гарантом збереження й примноження національних традицій в предметно-просторовому дизайні. Досвід показує, що закономірність, яка побудована на принципі - першоджерело, артефакт, автентика, дають більш глибокий та концептуальний кінцевий результат. Поверхневе, часто ідеологічно заангажоване інформативне поле, може цілковито маргілізувати розвиток повноцінного дизайну у всіх напрямках життєдіяльності соціуму, що суттєво спотворює ціннісний і гармонійний розвиток культурного балансу суспільства, яке бажає зберегти свою державну ідентичність (Черкес, 2006). Водночас і категорія ремісничої, саме авторської рукотворчості в дизайні повинна бути піднесена до високого рівня мистецтва, що і формує поняття індивідуального авторського інтер'єру, а це явище, у сьогоднішніх реаліях, трактується такою дефініцією, як гармонійний дизайн просторового середовища (Бойчук, О., 2017, 2019).

Виявлення та аналіз ідейно-філософських та естетичних витоків мистецької та дизайн-діяльності у контексті нових соціокультурних викликів освітнього розвитку диктує необхідність вибудовувати системну аналітичну базу методологічних принципів, що синтезує усі прийоми та засоби суміжних наук: мистецтвознавства, теорії та практики архітектурно-проектної діяльності, філософії, естетики, педагогіки, консерваційно-реставраційних принципів збереження пам'яток з універсальними для цих наук методами історичного, типологічного та порівняльного аналізу (Шмагало, 2020). В цьому контексті 
практична значущість таких міждисциплінарних досліджень сприяє формуванню глибинного філософсько-естетичного світогляду та глибокому рівню усвідомлення, формуванню сприйняття нових цінностей у явищах мистецької та дизайнерської практики, виокремленню нових парадигм та орієнтирів щодо впровадження та проектування креативних ідей розвитку в сучасній українській освіті, дизайн-діяльності та культурологічній концепції на шляху пошуку самоідентичності.

Для формування нових підходів та принципів слід запропонувати вже опрацьовану достовірну аналітичну базу, до якої може апелювати кожен творець та проектант. Науково аргументована, автентична база імплементується у свідомість сучасного творця, і від того, наскільки вона здатна формувати переосмислення творчих ідей, залежить і степінь філософського трактування та шляхів створення фундаментальних тенденцій розвитку базових національних мистецьких та дизайнерських шкіл. Цеховий вишкіл кінця XIX ст. поступово замінювався на вишкіл у фахових школах (Шмагало, Р., 2020), де широку підтримку отримала проектна, ручна творчість для реалізації неповторності та облаштування візуального світу за естетичними законами мистецтва. Означені мистецькою критикою циклічність, незалежно від значного впливу цифрових технологій, все ж завжди повертається до феноменального мистецького процесу рукотворної естетики. Таке співвідношення у короткому проміжку часу значно коливається. Досвід показує, що повна всеохоплююча машинізація, стремління до прагматизму та функціонального проектування, динамічності виконання та реалізації проектів, не змогли цілковито витіснити рукотворний сегмент 3 дизайну предметно-просторового середовища.

3 метою інспірувати та зберегти творчі принципи монументальних стінописів в предметно-просторовому дизайні опорядження інтер'єрів чи екстер'єрів, здійснено ряд експериментальних спроб використання теоретичноаналітичних положень, досліджень у сучасній проектно-дизайнерській, художній діяльності для формування нових методів використання історичних зразків в проектуванні гармонійного предметно-просторового середовища 
сучасного простору.

Це було реалізовано у ряді студентських проектів, скерованих апробувати на практиці художньо-проектну компонентну в дизайні простору та її практичну реалізацію вже безпосередньо на об’єкті. Завдання таких навчальних процесів спрямовані на пошуки шляхів інтерпретації, трансформації та модифікації досвіду, принципів індивідуального творчого методу певного художника чи творчої групи. Зокрема, в позааудиторному режимі студенти кафедри дизайну та основ архітектури Інституту архітектури і дизайну Національного університету «Львівська політехніка» реалізували ряд артпроектів, які були інспіровані творчим доробком львівського митця першої чверті XX століття Модеста Сосенка. В методологічній основі закладено трансформацію, інтерпретацію аналогів та творчих принципів монументальних структур та орнаментальних схем в практиці художнього оздоблення та образно-стилістичній організації інтер’єрного громадського простору конкретної локації інтер’єру (рис.1.).

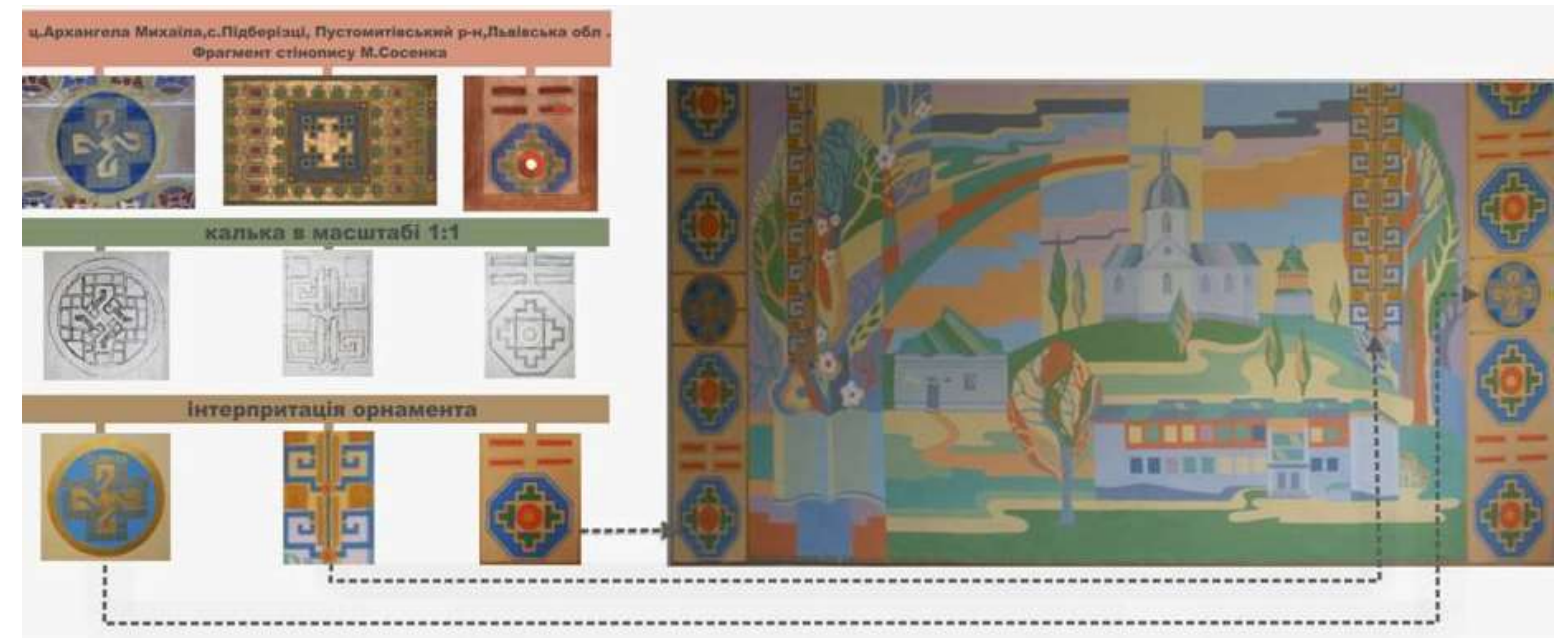

Рисунок 1.Художньо-виробнича практика студентів кафедри ДОА: виконання декоративномонументального панно, музична зала СШ №2, с. Підберізці (2011)

Втілення візуальних та морфологічних закономірностей орнаментальних схем М. Сосенка були використані для виконання великоформатного декоративного панно в актовій залі шкільного закладу с.Підберізців (куратор В.Радомська, 2011) у рамках живописно-пленерної практики студентів напрямку 022 «Дизайн» кафедри ДОА НУ «Львівська політехніка». Цей проект скерований на методично-науковий та практичний підхід формування концепції передпроектного аналізу, оскільки за визначеними критеріями було обрано 
візуальний ряд для ідейно-змістового наповнення настінного панно, продумано способи окреслення регіональних та краєзнавчих особливостей с. Підберізців (Львівська обл.). Оскільки це село відоме, перш за все, за визначною пам’яткою - стінописами Модеста Сосенка (1907-1910) в місцевій церкві Арх. Михаїла, прийнято концепцію інтегрувати композиційні принципи орнаментальних схем у структуру новоствореного проекту (художник Ю. Кіндзер). Була обрана наступна тактика: вирахувавши певну співмасштабність, знято кальки 3 автентичних орнаментальних елементів стінопису інтер'єру церкви вертикальний сегмент орнаментальної схеми з відкосу вікна північної стіни нави, хрещатий символ (сварга) орнаменту з нижнього регістру південної стіни нави, стрічковий орнамент з підпружної арки хорів, що дозволило студентам наочно ознайомитись 3 техніко-технологічними аспектами творчого методу М. Сосенка, визначити композиційну структуру самого орнаментального блоку, принцип його побудови та утворення, його співмасштабність та колористичну співтональність, визначити співвідношення величини архітектонічної деталі храму з масштабами проекту сучасного стінопису. Кальки виконані у масштабі 1:1 згідно оригіналу стінописів. Було обрано орнаментальний фриз віконного відкосу північної стіни рамена трансепту, який, згідно пропорцій, стилістики та масштабів, добре компонувався у загальну концепцію задуму проекту. Наступний взірець орнаменту було знято із орнаментального фризу підпружної арки на хорах. Процес зняття кальок проводили у декілька прийомів. 3 метою відтворення техніко-технологічних особливостей творчого підходу Модеста Сосенка було здійснено наступний етап роботи - виготовлення та апробування на практиці «припорохів», які митець застосовував як технічний прийом для перенесення рисунку на поверхню стін та склепінь. Звичайно, що у сучасних умовах художники-монументалісти використовують новітні методики перенесення та нанесення рисунку, композиційних частин задуму. Але згідно мети та завдання художньої практики, студенти повинні були пройти апробацію художньо-технічних процесів із застосуванням давніх технології та визначеного індивідуального творчого методу обраного художника. Для виготовлення 
«кальок» використано сучасний матеріал - цупка поліетиленова плівка, яку згодом перфоровано (проколювання певного калібру), через отвори наносили порошкоподібний пігмент, згодом уточнюючи деякі деталі рисунку графітним олівцем. Таким чином оригінальні сегменти орнаментальних схем М. Сосенка (натуральний масштаб) були вкомпоновані у загальну композиційну структуру задуму декоративного панно (рис. 2).

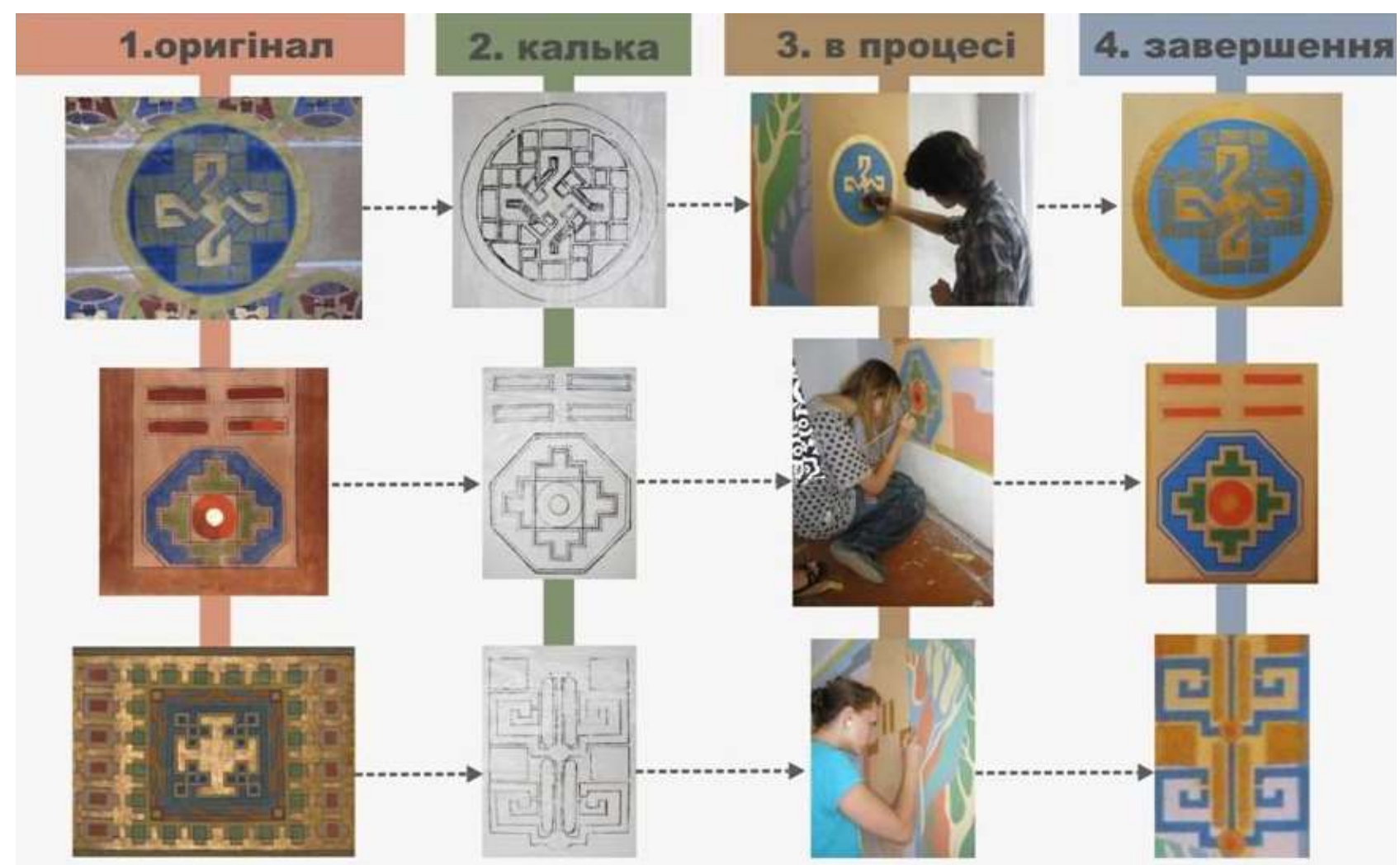

Рисунок 2. Техніко-технологічна методологія виконання декоративно-монументального панно для музичної зали СШ №2, с. Підберізці (2011), студенти Дз-22,кафедри ДОА,куратор В. Радомська.

Позитивний досвід був інтегрований у наступному проекті для образноестетичного наповнення музичної зали дошкільного закладу № 32 у Львові. Для реалізації цих стінописів було використано дещо інший підхід, площиннодекоративні елементи орнаментальних першовзорів зі стінописів Музичного інституту у Львові та елементів орнаментальних сегментів 3 інтер'єрного стінопису церкви Арх. Михаїла с. Підберізців, поєднані в одну образно-стильову композиційну систему, які і створили сучасну образно-стильову програму для даних стінописів (2011). 3 цією метою, згідно проекту, було виготовлено 
трафарети та шаблони, що дозволило в інший спосіб перенести рисунок задуму, оскільки високі стелі приміщення дещо ускладнювали застосування попередньої техніко-технологічної методики, апробованої при створенні декоративного панно для концертної зали в с.Підберізцях.

Монументальна спадщина М. Сосенка стала базовими аналогом для дипломного проектування студентки кафедри дизайну та основ архітектури Г. Піщук (Дз-42, 2011 р., ОКР «Бакалавр») - здійснено експериментальне проектування, яке було базоване на художньому конструюванні предметного обладнання, а саме розробці дизайну меблів-трансформерів та експозиційного обладнання для музейного простору краєзнавчого музею в с. Підберізці Львівської обл. Авторка проекту обрала певні елементи з композиційних блоків стінописів М.Сосенка, які стали формоутворюючими конструктивними елементами предметного обладнання музейного простору. В комплексному проектування було розроблено буклет музею та серію сувенірно-поліграфічної продукції (листівок, магнітів, постерів тощо), в яких композиційні та образноестетичні принципи схем орнаментальних мотивів стінописів М. Сосенка стали предметом творчої інспірації.

Проблематика сакрального дизайну піднята у дипломному проектуванні магістерської роботи М.Олійник, яка взяла участь у реальній розробці комплексної дизайн-пропозиції для організації предметно-просторового опорядження Патріаршого собору Воскресіння Господнього у Києві (УГКЦ), (2013, дизайн: А. Тирпич, М. Олійник, ст. ДЗ3В-11 ДОА ІАРД). Було розроблено усю богословську інфраструктуру опорядження храму, зокрема, компонентів обладнання для богословсько-обрядового освітлення. Мотивом для творчої інспірації у формотворенні послужила фрактальна структурність геометричних орнаментальних патернів стінопису М. Сосенка. У даній роботі розуміння орнаменту як засобу лише декоративного оздоблення і прикраси було цілковито відкинуте. В розробці домінувава принцип розкриття суті орнаменту, як складної формоутворючої структури, яка закладає силует і водночас стає об'ємнопростровою конструкцією з яскраво вираженою функціональною причетністю. 
Візуальне відтворення у формах ужитково-функціонального призначення, а літургійно-обрядове освітлення в інтер'єрі церкви відіграє конкретну та важливу богословську функцію, здійснено за допомогою образно-асоціативних прийомів формотворення. Образні асоціації сформовані за допомогою орнаменту, їх ажурів та переплетень, з використанням закономірностей психології візуального сприйняття, візуальних та морфологічних властивостей базових геометричних фігур. В проекті застосовано співмасштабування квадратного січення металічної конструкції та формотворення на основі геометричних співставлень хрещатих рівнораменних фігур та концентричних об'ємів, які одночасно виконують і конструктивно-технічну та образо-творчу функції. Доповнення елементів 3 гутного скла надають довершеності та функціонального призначення усьому запроектованому обладнанню. Тобто, у даній дизайн-пропозиції авторка вдало та органічно поєднала візуальні образні властивості та прикладне значення сакрального предметного наповнення. Використовуючи семантичну символіку хрещатих мотивів, автор підкреслює зміст, а це і є пряма функція та завдання орнаменту.

В контексті освітнього процесу в сучасній мистецько-дизайнерській освітній практиці для графічного дизайну використано прототипи орнаментальних напрацювань М. Сосенка для створення айдентики «Доброчинного фонду Модеста Сосенка». Орнаментальні мотиви, вітражні композиції авторства М.Сосенка, які знаходяться в інтер'єрному просторі святилища церкви Арх. Михаїла с. Підберізців, стали об’єктами інспірації у розробці серії поштових марок у графічному дизайні студентки кафедри дизайну та основ архітектури ІАРД О.Головатої (2021, Д3-42).

Мистецько-освітня практика, яка спрямована на вивчення й використання закономірностей орнаментальних мотивів, залежить від багатьох факторів, зокрема, від оригінальності представлених проектних ідей та вміння донести проектний задум на належному дизайнерському рівні. Виявлення шляхів та механізмів втілення візуальних закономірностей орнаментики чи іконографічної програми обраних прототипів в сучасній мистецько-дизайнерській практиці 
грунтується на основі використання теоретичного підходу й власного практичного досвіду дизайнера, розуміння тенденцій проектування сучасних інтер'єрів та їх предметного наповнення. Тому перший етап - збагачення та формування правдивої інформативної бази як в освітньому процесі, так і в індивідуальному фаховому проектуванні об’єктів, дозволяє виявити закономірності, методи, прийоми для оптимальної організації інтер'єру, зокрема і за посередництвом стінописів чи інших артоб'єктів. Предметно-просторове опорядження інтер'єру у значній мірі залежить від гармонізації усіх компонентів та коректного скерування усіх складових - образотворчої мистецької програми та ужитково-функціонального обладнання. Це реальна можливість отримати найвищий рівень синтезу художніх практик, підпорядкованих єдиному концептуальному задуму. Тобто на етапі проекту дизайнер не може залишати реалізацію задуму спонтанному виконанню, як правило, це завершується невдалою реалізацією.

Накопичені знання впливають на формування світоглядних пріоритетів теоретичного підгрунтя та мислення проектанта (студента), і можуть цільово, свідомо та на інтуїтивному рівні бути застосованими при виникненні відповідних проектних ситуацій. Зафіксована у пам'яті візуально-теоретична інформація згодом відображається як характерний та доцільний формоутворюючий та образний архетип. Цю тенденцію спостерігаємо в практиках більш сформованих дизайнерів.

Тому досвід реалізація позааудиторних артпроектів, які започатковані 3 2006 року в структурі дизайн-освіти для студентів напрямку 022 «Дизайн»на кафедрі Дизайну та основ архітектури (керівник та куратор - стар. вик. каф. ДОА В.Радомська), надали можливість творчо та неординарно застосувати академічні знання на практиці. 3 цією метою було реалізовано понад десяток цікавих художніх проектів у формі позааудиторних воркшопів. Основне завдання таких заходів - при допомозі стилістично об'єднаних живописних полотен, стінописів створити художньо-естетичне наповнення та організацію інтер'єрного простору конкретної локації. В основному, задіяні інтер'єри 
шкільних та дошкільних закладів, музеїв, лікарняних установ, геріатричні пансіонати тощо. Найбільш знакові проекти: облаштування художньомеморіального музею М. Сосенка в с. Підберізцях Львівскої області (2008р.); стінопис-панно актової зали СШ № 2 с. Підберізців (2009р.); айдентика, декоративне панно, копії творів Осипа Куриласа для експозиції меморіальнохудожнього музею О. Куриласа (2012-2016, м. Щирець Львів. обл.); ряд великоформатних панно за мотивами творів В. Зарицького для інтер'єрного наповнення актової зали СЗОШ № 28 (2013-2017, м. Львів); 2016-2018pp. реалізовано художній проект «С.Караффа-Корбут: трансформація і реалізація» на основі художньої та змістової інтерпретації циклу ілюстрацій художниці до творів І. Франко, А. Волощака, Л. Українки (СШ № 9, м. Львів), що дозволяє на практиці методично інтегрувати нові форми інтелектуального фахового сегменту у позааудиторний навчальний процес дизайнерів на кафедрі ДОА.

За посередництвом глибокого аналізу персоніфікованих інтер'єрів, оригіналів, ідентифікованих артефактів та визначених архетипів в сучасній дизайн-освіті формуються нові ідеї для подальшого створення актуальних форм та естетичних пріоритетів, які згодом стають ретрансляторами ідентичності. 